\title{
Extraction and separation of cadmium and nickel from two-phase aqueous systems by the method of liquid extraction, corresponding to the concept of "green chemistry"
}

\author{
(C) Roman D. Tangalychev, ${ }^{1 *}$ Nikolay B. Berezin, ${ }^{2+}$ Zhanna V. Mezhevich ${ }^{2}$, \\ Sergey V. Buzov, ${ }^{2}$ and Stanislav R. Temnikov ${ }^{3}$ \\ ${ }^{1}$ Department of Processes and Apparatuses of Chemical Technology. Moscow Polytechnic \\ University. Bolshaya Semenovskaya St., 38. Moscow, 107023. Russia. \\ Phone: +7910600 1164.E-mail:1supergod1@gmail.com \\ ${ }^{2}$ Department of Technology of Electrochemical, Production; \\ ${ }^{3}$ Department of Food Production Equipment. Kazan National Research Technological University. \\ K. Marx St., 68. Kazan, 420015. Republic of Tatarstan. Russia. \\ Phone:+7 (843) 231-95-06.E-mail: berezintep@yandex.ru
}

*Supervising author; ${ }^{+}$Corresponding author

Keywords: extraction, separation, cadmium, nickel, chemical current source, liquid extraction.

\section{Abstract}

Extraction of valuable metals from chemical current sources allows not just to solve the problem of their disposal, but also to prevent environmental pollution. This approach is of particular importance in the case of the presence of toxic metals in chemical current sources, such as cadmium. Cadmium is known to have general toxic, mutagenic and teratogenic effects on living organisms. Nickel can cause allergic reactions and have a general toxic effect. According to some reports, nickel has a carcinogenic and mutagenic effect.

The aim of the work is to obtain data on the extraction and separation of cadmium and nickel during the disposal of chemical current sources by liquid extraction, depending on the process conditions.

The work obtained data on the separation, extraction of cadmium and nickel from $\mathrm{Ni}-\mathrm{Cd}$ chemical current sources (CCS) using an two-phase aqueous extraction system consisting of polyethylene glycol (PEO1500), a phase-forming salt of $\mathrm{Na}_{2} \mathrm{SO}_{4}$ and water. The extraction behavior of metals and their separation into lower and upper phases using an extractant, potassium iodide, was studied. The maximum recovery of $\mathrm{Cd}$ $(99.2 \pm 1) \%$ and $\mathrm{Ni}(89.4 \pm 1) \%$ is achieved by leaching the batteries with $\mathrm{HCl}$ under the following conditions: KI concentration of $3 \mathrm{~g} / \mathrm{l}$, dilution coefficient of the CCS solution is 35 . The liquid extraction method used in this work has been shown to be effective for the separation of the metals in question and has an advantage in terms of environmental safety. This extraction technique corresponds to the concept of "green chemistry".

\section{References}

[1] N.B. Berezin, M.N. Mavletov, A.Z. Yarullin, Zh.V. Mezhevich. Modified electrolytes based on amino complexes. Butlerovskie Communications. 2016. Vol.48. No.11. P.58-70. DOI: 10.37952/ROI-jbc-16-4811-58

[2] M.B.J.G. Freitas, T.R. Penha, S. Sirtoli. Chemical and electrochemical recycling of the negative electrodes from spent Ni-Cd batteries. J. Power Sources. 2007. No.163. P.1114-1119.

[3] B.R. Reddy, D.N. Priya, Rao and P. Radhika S.V. Solvent Extraction and Separation of Cd(II), Ni(II) and $\mathrm{Co}$ (II) from Chloride Leach Liquors of Spent Ni-Cd Batteries Using Commercial Organo-Phosphorous Extractants. Hydrometallurgy. 2005. Vol.77. No.3-4. P.253-261.

[4] B.R. Reddy, D.N. Priya, K.H. Park. Solvent extraction and separation of Cd(II), Ni(II) and Co(II) from chloride leach liquors of spent $\mathrm{Ni}-\mathrm{Cd}$ batteries using commercial organo-phosphorus extradants. Sep. Purif. Technol. 2006. Vol.50. P.161-166.

[5] S.S. Vinogradov. Environmentally friendly galvanic production. Moscow: Globus. 1998. 302p. (russian)

[6] C.A. Nogueira, F. Margarido. Chemical and physical characterization of electrode materials of spent sealed Ni-Cd batteries. Waste Manage. 2007. Vol.27. P.1570-1579.

[7] M. Sadegh Safarzadeh, M.S. Bafghi, D. Moradkhani, M. Ojaghi Ilkhchi. A review on hydrometallurgical extraction and recovery of cadmium from various resources. Miner.Eng. 2007. No.20. P.211-220.

[8] C.A. Nogueira, F. Delmas. New flowsheet for the recovery of cadmium, cobalt and nickel from spent NiCd batteries by solvent extraction. Hydrometallurgy. 1999. No.52. P.267-287. 
EXTRACTION AND SEPARATION OF CADMIUM AND NICKEL FROM TWO-PHASE AQUEOUS SYSTEMS... 58-63

[9] M.B.J.G. Freitas, S.F. Rosalém. Electrochemical recovery of cadmium from spent Ni-Cd batteries. Journal of Power Sources. 2005. No.139. P.366-370.

[10] B.R. Reddy and D.N. Priya. Chloride leaching and solvent extraction of cadmium, cobalt and nickel from spent nickel-cadmium, batteries using Cyanex 923 and 272. J. Power Sources. 2006. No.161. P.1428-1434.

[11] Yu.Yu. Lurie. Handbook of analytical chemistry. 5th ed. reslave. and add. Moscow: Chemistry. 1979. 480p. (russian) 